\title{
Alternatif Terapi Inisial Sindrom Nefrotik untuk Menurunkan Kejadian Relaps
}

\author{
Reni Wigati, Eka Laksmi \\ Departemen Ilmu Kesehatan Anak, RS Dr Cipto Mangunkusumo, Fakultas Kedokteran Universitas \\ Indonesia, Jakarta
}

\begin{abstract}
Sindrom nefrotik (SN) merupakan penyakit ginjal yang paling sering ditemukan pada anak. Pernberian steroid sebagai terapi $\mathrm{SN}$ telah terbukti efektif untuk mencapai kondisi remisi (94\%) namun insidens relaps masih tinggi, yaitu hampir 60\%. Untuk tata laksana SN pada anak di Indonesia, Unit Kerja Koordinasi Nefrologi Ikatan Dokter Anak indonesia telah menyusun konsensus sesuai dengan rekomendasi empiris International Study for Kidney Disease in Children (ISKDC). Terapi inisial diberikan prednison dosis penuh $60 \mathrm{mg} / \mathrm{m}^{2} \mathrm{LPB} /$ hari selama empat minggu dilanjutkan dengan dosis $40 \mathrm{mg} / \mathrm{m}^{2} \mathrm{LPB} / \mathrm{hari}$ selang sehari selama empat minggu (terapi standar). Makalah ini membahas perbandingan terapi standar dengan terapi inisial yang diperpanjang atau dikombinasi dengan obat imunosupresif lain, apakah terapi alternatif ini dapat mengurangi kejadian relaps tanpa meningkatkan efek samping. Kesimpulan dari telaah ini adalah prednison inisial yang diperpanjang terbukti dapat menurunkan kejadian relaps tanpa meningkatkan efek samping yang berarti. Alternatif lain yaitu kombinasi prednison dengan siklosporin A yang tampaknya jugs menjanjikan hasil yang balk. (Sari Pediatri 2010;11(6):415-19).
\end{abstract}

Kata kunci: sindrom nefrotik, prednison, urinalisis

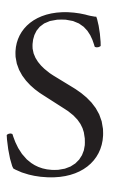

indrom nefrotik (SN) adalah sindrom klinis akibat perubahan selektivitas permeabilitas dinding kapiler glomerulus sehingga protein dapat keluar melalui urin. Pada anak, SN merupakan penyakit ginjal yang paling sering ditemukan. ${ }^{1,2}$ Pada tahun 1992, Wirya IGNW ${ }^{3}$ melaporkan insidens SN enam kasus per 100.000 anak di Indonesia, sementara Divisi Nefrologi Ilmu Kesehatan Anak (IKA) RS Cipto Mangunkusumo

\section{Alamat korespondensi:}

Dr. Eka Laksmi, Sp.A. Divisi Nefrologi. Departemen Ilmu Kesehatan Anak Fakultas Kedokteran Universitas Indonesia Jl. Salemba no. 6, Jakarta 10430. Telepon: 021-3915179. Fax.021-390 7743.
(RSCM) mencatat sekitar 130 kasus baru selama tahun 2004 sampai 2008.

Unit Kerja Koordinasi Nefrologi Ikatan Dokter Anak Indonesia menyusun konsensus tata laksana SN pada anak sesuai dengan rekomendasi empiris International Study for Kidney Disease in Children $(I S K D C)$. Terapi inisial dimulai dengan prednison dosis penuh sebesar $60 \mathrm{mg} / \mathrm{m}^{2}$ luas permukaan badan (LPB)/hari selama empat minggu dan dilanjutkan dengan dosis $40 \mathrm{mg} / \mathrm{m}^{2} \mathrm{LPB} /$ hari selang hari untuk empat minggu berikutnya (terapi standar). ${ }^{1,2}$

Tujuan terapi SN untuk mencapai remisi, mencegah relaps, dan menghindari efek samping obat. Sebagian besar SN pada anak memberikan respons yang baik 
terhadap terapi inisial steroid (94\%). Masalah yang timbul adalah insidens relaps yang tinggi yaitu hampir $60 \%$ sehingga morbiditas dan mortalitas meningkat, serta efek samping pengobatan yang ditimbulkan lebih berat. Keadaan tersebut sangat mempengaruhi kualitas hidup dan kesintasan seorang anak dengan $\mathrm{SN} .^{2,4-7}$ Sajian kasus ini bertujuan untuk membandingkan berbagai alternatif terapi inisial SN untuk menurunkan kejadian relaps tanpa meningkatkan efek samping obat.

\section{Kasus}

Seorang anak laki-laki berusia 6 tahun datang ke Poliklinik Nefrologi Departemen Ilmu Kesehatan Anak RS Dr. Cipto Mangunkusumo (IKA RSCM) dengan keluhan utama bengkak seluruh tubuh, hilang timbul sejak 8 bulan yang lalu. Keluhan buang air kecil berkurang atau berwarna kemerahan disangkal. Pasien telah dibawa berobat ke dokter umum dan dikatakan mengalami kebocoran ginjal. Dokter tersebut memberikan terapi berupa tablet hijau sembilan tablet $(2 \mathrm{mg} / \mathrm{kgBB} /$ hari $)$ setiap hari namun ibu tidak ingat berapa lama total pemberian dosis tersebut karena diturunkan menjadi empat tablet $(1 \mathrm{mg} / \mathrm{kgBB} /$ hari) setiap hari setelah dilakukan pemeriksaan urin, dikatakan membaik. Pasien masih diberikan obat hingga saat ini karena protein di dalam urin belum pernah negatif. Akhirnya pasien dirujuk ke RSCM karena bengkak masih hilang timbul walaupun telah diterapi selama delapan bulan. Anggota keluarga yang lain tidak ada yang diketahui memiliki sakit ginjal. Pasien berasal dari keluarga golongan sosial ekonomi menengah ke bawah. Riwayat kehamilan, persalinan, dan tumbuh kembang normal. Pasien telah mendapatkan imunisasi dasar lengkap dan asupan nutrisi yang cukup baik.

Pada pemeriksaan fisis di poliklinik, pasien kompos mentis, tidak sesak maupun sianosis. Berat badan $20 \mathrm{~kg}$, tinggi badan $115 \mathrm{~cm}$, dan lingkar lengan atas $16,5 \mathrm{~cm}$ dengan status gizi baik. Tanda vital terukur dalam batas normal dengan tekanan darah 90/60 $\mathrm{mmHg}\left(<\mathrm{P}_{95}\right.$ tabel tekanan darah menurut usia dan tinggi badan). Edema ditemukan pada area palpebra dan pretibia. Tanda-tanda toksisitas steroid tidak ditemukan. Proteinuria +3 dideteksi pada urinalisis dan tidak terdapat hematuria. Pemeriksaan penunjang lain menunjukkan hipoalbuminemia $1,5 \mathrm{~g} / \mathrm{dL}$ dan hiperkolesterolemia $435 \mathrm{mg} / \mathrm{dL}$, sementara fungsi ginjal masih baik (ureum $7 \mathrm{mg} / \mathrm{dL}$ dan kreatinin 0,4 $\mathrm{mg} / \mathrm{dL}$ dengan laju filtrasi glomerulus $158 \mathrm{~mL} / \mathrm{menit} /$ $\left.1,73 \mathrm{~m}^{2}\right)$.

Diagnosis sindrom nefrotik ditegakkan dan terapi inisial standar diberikan yaitu prednison delapan tablet setiap hari $(2 \mathrm{mg} / \mathrm{kg} /$ hari). Satu minggu kemudian, pasien kontrol dan menunjukkan perbaikan yaitu bengkak menghilang dan proteinuria menjadi \pm (trace). Setelah 2 minggu terapi inisial, urinalisis menunjukkan proteinuria negatif sehingga pasien dinyatakan remisi. Pasien tetap dalam keadaan remisi setelah menjalankan terapi standar selama 8 minggu sehingga pengobatan dihentikan. Namun dua bulan kemudian, pasien mengalami relaps $S N$ pasien tampak bengkak dan terdapat proteinuria $(+4)$. Pasien kembali menjalani terapi standar dan saat ini memasuki prednison dosis penuh minggu kedua.

\section{Masalah klinis}

Pemberian steroid sebagai terapi SN telah terbukti efektif untuk mencapai kondisi remisi namun belum efektif untuk mencegah relaps. Banyak penelitian dirancang oleh para klinisi untuk menurunkan kejadian relaps sehingga aktivitas penyakit serta efek samping obat pada pasien diharapkan turut berkurang. Berdasarkan masalah tersebut, pertanyaan klinis diajukan sebagai berikut: "Pada anak dengan $\mathrm{SN}$, apakah terapi prednison yang diperpanjang atau penggunaan imunosupresif lain pada terapi inisial dibandingkan terapi standar dapat mengurangi kejadian relaps tanpa meningkatkan efek samping obat?"

\section{Metode penelusuran}

Prosedur pencarian literatur untuk menjawab masalah klinis tersebut dengan menelusuri pustaka secara online dengan menggunakan instrumen pencari Pubmed, Highwire, Cochrane Library, Google, dan Yahoo. Kata kunci yang dipergunakan adalah "nephrotic syndrome", "steroid sensitive", alternative, "initial therapy", dan relapse dengan menggunakan batasan, studi dilakukan pada manusia, publikasi bahasa Inggris, publikasi 10 tahun terakhir, usia subjek penelitian 0-18 tahun, dan kata kunci terdapat pada judul atau abstrak. 
Dengan metode tersebut, penulis mendapatkan 43 artikel yang memenuhi kriteria. Penelusuran lebih lanjut dilakukan secara manual pada daftar pustaka yang relevan. Setelah penelusuran judul dan abstrak, 14 artikel dipilih karena paling relevan dengan masalah, terdiri dari satu artikel meta analisis, enam artikel uji klinis acak terkontrol, dua artikel kohort, dan lima artikel review. Levels of evidence ditentukan berdasarkan klasifikasi yang dikeluarkan oleh Oxford Centre for Evidence-based Medicine Levels of Evidence. ${ }^{8}$

\section{Hasil penelusuran}

Beberapa penelitian melaporkan keunggulan terapi prednison yang diperpanjang (kelompok intervensi) yaitu $60 \mathrm{mg} / \mathrm{m} 2 \mathrm{LPB} /$ hari atau $2 \mathrm{mg} / \mathrm{kgBB} /$ hari selama 6 minggu dilanjutkan dengan $40 \mathrm{mg} / \mathrm{m} 2 \mathrm{LPB} /$ hari atau $1,5 \mathrm{mg} / \mathrm{kgBB} /$ hari secara selang hari selama 6 minggu bila dibandingkan dengan terapi standar (kelompok kontrol). Sebuah meta analisis oleh Hodson EM dkk9 melibatkan 1726 anak dengan SN dalam 24 penelitian. Peneliti menelaah delapan penelitian yang membandingkan terapi inisial dengan prednison selama dua bulan dengan tiga bulan atau lebih dan menyimpulkan terapi yang lebih lama akan menurunkan risiko relaps pada 12 dan 24 bulan pertama setelah episode awal sakit (RR 0,7 dengan interval kepercayaan $95 \%=0,58-0,84)$. Selain itu, hubungan linear terbalik juga ditunjukkan antara durasi terapi dan risiko relaps pada pemantauan 12 dan 24 bulan. Korelasi sedang $\left(\mathrm{r}^{2}=0,56\right)$ dinyatakan antara durasi terapi diperpanjang dengan risiko relaps pasien $S N$ yang berkurang (nilai $\mathrm{p}=0,03$ ). Peningkatan efek samping yang serius pada kelompok intervensi tidak ditemukan pada analisis ini (level of evidence: $1 a$ ).

Bagga A dkk ${ }^{10}$ melakukan sebuah uji klinis acak terkontrol terhadap 51 kasus $\mathrm{SN}$ inisial. Hasil penelitian tersebut memperlihatkan bahwa relaps pertama kali terjadi lebih lama pada kelompok intervensi (prednison 12 minggu) dibandingkan kelompok kontrol (prednison 8 minggu) yaitu mean 222,2 hari; median 120,0 versus mean 134,3; median 96,5 hari dengan nilai $\mathrm{p}=0,2$. Persentase pasien yang tidak mengalami relaps sama sekali pada 6 dan 12 bulan setelah terapi dihentikan mencapai $40,9 \%$ dan $27,3 \%$ pada kelompok intervensi, sementara hanya $21,7 \%$ dan $8,7 \%$ pada kelompok kontrol. Perbedaan ini bermakna secara klinis namun tidak bermakna secara statistik dimungkinkan karena besar sampel kurang (level of evidence: 1b).
Penelitian efektivitas prednison yang diperpanjang hingga 12 minggu di Indonesia cenderung menyerupai penelitian-penelitian di luar negeri. Pada tahun 2002, Trihono PPT dkk ${ }^{11}$ melaporkan uji klinis acak terkontrol yang dilakukan terhadap 18 kasus SN yang diobati di Divisi Nefrologi Departemen IKA RSCM. Pemantauan dilakukan hingga satu tahun untuk menilai kekerapan relaps. Peneliti menyimpulkan bahwa terdapat kecenderungan relaps lebih jarang bila mendapat terapi prednison selama 12 minggu. Relaps pertama kali timbul dalam 4 minggu setelah pengobatan dihentikan terjadi pada 2 dari 8 anak kelompok intervensi (prednison 12 minggu) dan 3 dari 10 anak kelompok kontrol (prednison 8 minggu). Relaps 2 kali atau lebih dalam 6 bulan pertama setelah pengobatan dihentikan terdapat pada 2 anak kelompok intervensi dan 4 anak kelompok kontrol. Sementara itu, relaps 4 kali atau lebih dalam satu tahun setelah pengobatan dihentikan tidak ditemukan pada kelompok intervensi, namun didapatkan pada 2 anak kelompok kontrol. Jumlah anak yang tidak pernah mengalami relaps selama satu tahun pemantauan adalah 2 anak dalam kelompok intervensi dan 1 anak dalam kelompok kontrol. Efek samping tidak ditemukan pada hampir semua sampel penelitian kecuali pada satu anak dalam kelompok kontrol mengalami toksid steroid (Uji klinis acak terkontrol, level of evidence: tidak cukup data untuk ditentukan).

Penelitian lain dilaporkan oleh Noer $\mathrm{MS}^{12}$ pada tahun 2005, suatu uji klinis acak terkontrol melibatkan 81 anak dengan SN di Departemen IKA RS Dr. Soetomo Surabaya. Rerata relaps pertama kali timbul pasca-pengobatan dihentikan lebih lama pada kelompok intervensi (prednison 12 minggu) yaitu $272,28( \pm 158,76)$ hari bila dibandingkan dengan kelompok kontrol (prednison 8 minggu) yaitu 238,02 $( \pm 144,28)$ hari (nilai $\mathrm{p}=0,32)$. Namun demikian, dosis kumulatif prednison yang diterima oleh kelompok intervensi lebih besar daripada kontrol yaitu 3.012,2 $\mathrm{mg}$ dan $2.087,1 \mathrm{mg}$ (nilai $\mathrm{p}=0,002$ ) (level of evidence: 1b).

Pemikiran mengenai terapi prednison yang lebih lama akan lebih efektif dibandingkan terapi standar membuat penelitian dirancang untuk mengetahui pola regimen yang paling baik. Hiraoka $M \mathrm{dkk}^{13}$ membandingkan keluaran antara dua regimen terapi prednison yang diperpanjang dalam sebuah uji klinis acak terkontrol pada tahun 2003. Kelompok kontrol 
mendapatkan terapi $60 \mathrm{mg} / \mathrm{m}^{2} \mathrm{LPB} /$ hari selama 6 minggu dan dilanjutkan $40 \mathrm{mg} / \mathrm{m}^{2} \mathrm{LPB} /$ hari secara selang hari selama 6 minggu. Kelompok intervensi diterapi dengan $60 \mathrm{mg} / \mathrm{m}^{2} \mathrm{LPB} / \mathrm{hari}$ selama 4 minggu, dilanjutkan dengan $60 \mathrm{mg} / \mathrm{m}^{2} \mathrm{LPB} /$ hari selang hari selama 4 minggu, serta dilakukan tapering off setiap 4 minggu, $10 \mathrm{mg} / \mathrm{m}^{2} \mathrm{LPB}$. Kelompok intervensi menunjukkan insidens toksisitas kortikosteroid lebih rendah daripada kelompok kontrol. Analisis kesintasan durasi remisi antara kedua kelompok sebenarnya secara statistik tidak berbeda bermakna (nilai $\mathrm{p}=0,069$ ) namun bermakna setelah dilakukan stratifikasi terhadap umur saat awal penyakit. Pada subkelompok dengan usia lebih muda (kurang dari 4 tahun saat onset), analisis Kaplan-Meier menunjukkan durasi remisi yang lebih lama (nilai $\mathrm{p}=0,003$ ) dan lebih sedikit sampel yang mengalami relaps sering (nilai $\mathrm{p}=0,048$ ) pada kelompok intervensi (level of evidence: 1b).

Hipotesis bahwa jumlah agen imunosupresif mempengaruhi angka kejadian relaps mendasari Hoyer $\mathrm{PF} \mathrm{dkk}^{5}$ menguji efektivitas siklosporin sebagai bagian dari terapi inisial SN pada tahun 2006. Uji klinis acak terkontrol ini membandingkan antara terapi $60 \mathrm{mg} /$ $\mathrm{m}^{2} \mathrm{LPB} /$ hari selama 6 minggu yang dilanjutkan 40 $\mathrm{mg} / \mathrm{m}^{2} \mathrm{LPB} / 48$ jam selama 6 minggu selang hari $(55$ kasus) dengan terapi yang serupa namun dikombinasi dengan siklosporin A $150 \mathrm{mg} / \mathrm{m}^{2} \mathrm{LPB} /$ hari selama 8 minggu (49 kasus). Kelompok yang mendapatkan siklosporin A dapat mempertahankan masa remisi lebih lama yaitu rerata relaps pertama kali 22,8 bulan setelah pengobatan selesai, sementara kelompok yang hanya mendapatkan prednison memiliki rerata relaps pertama kali 12,5 bulan setelah pengobatan selesai (nilai $\mathrm{p}=0,01$ ). Ditambah lagi, rerata relaps per pasien kelompok yang mendapat siklosporin lebih rendah yaitu 0,12 versus 0,57 pada 6 bulan pengamatan (nilai $\mathrm{p}=0,01) ; 0,63$ versus 1,03 setelah 1 tahun pengamatan (nilai $\mathrm{p}=0,01$ ); dan 1,03 vs 2,06 pada akhir pengamatan ( 2 tahun) dengan nilai p yang tidak bermakna (nilai $\mathrm{p}=0,1)$ (level of evidence: $1 b$ ).

\section{Pembahasan}

Terapi medikamentosa merupakan salah satu bagian penting dari tata laksana holistik kasus anak dengan SN. Sebagian besar pasien dapat mencapai keadaan remisi setelah mendapatkan terapi steroid namun berbagai penelitian dilakukan untuk menetapkan regimen yang paling efisien dan efektif akibat angka kejadian relaps yang masih tinggi. ${ }^{4,5,9}$

Diagnosis SN pada pasien kami ditegakkan berdasarkan keluhan bengkak, ditemukannya proteinuria, hipoalbuminemia, serta didukung dengan adanya hiperkolesterolemia. Durasi dosis prednison penuh yang pernah diterima pasien tidak jelas sehingga terapi inisial diberikan sesuai dengan terapi untuk SN sensitif steroid. Respons awal pasien dinilai baik karena secara klinis membaik dan hasil urinalisis saat berobat jalan satu minggu kemudian. Pasien tetap memenuhi kriteria remisi setelah mendapatkan steroid dosis penuh selama empat minggu dan bertahan dalam keadaan remisi pada dosis selang hari selama empat minggu berikutnya. Namun dua bulan pasca-terapi prednison dihentikan, pasien dinyatakan relaps. Keadaan tersebut sesuai dengan literatur bahwa lebih dari $90 \%$ kasus SN inisial dapat mencapai remisi, bahkan dalam dua minggu pertama pengobatan, namun sebagian besar akan mengalami episode sakit kembali. ${ }^{2}$

Constantinescu AR $\mathrm{dkk}^{14}$ melaporkan semakin cepat pasien memberikan respons terhadap terapi prednison dapat mengurangi kemungkinan kejadian relaps dalam satu tahun pertama pasca-pengobatan dihentikan pada pasien tanpa hematuria. Profil klinis pasien kami saat awal diagnosis sesuai dengan subyek penelitian tersebut yaitu tidak terdapat hematuria dan sudah memenuhi kriteria remisi setelah satu minggu mendapat prednison dosis penuh. Di luar prediksi, pasien sudah mengalami relaps pada pemantauan dua bulan pasca-terapi steroid dihentikan. Hal ini mendukung bahwa terapi standar yang dilakukan di Indonesia dapat membuat seorang pasien $\mathrm{SN}$ remisi walaupun kemungkinan untuk relaps masih tinggi.

Pada awalnya, pemikiran untuk memperpanjang terapi steroid tidak disukai karena terdapat penelitian yang menyimpulkan bahwa terapi tersebut dapat menekan kejadian relaps namun meningkatkan efek samping toksik steroid. Pendapat tersebut akhirnya mulai ditinggalkan karena metaanalisis terbaru menemukan bahwa terapi selama 12 minggu dapat menurunkan risiko relaps dibandingkan 8 minggu tanpa meningkatkan kejadian efek samping obat yang serius. Pasien yang menerima prednison selam 12 minggu memang lebih berisiko untuk mengalami striae dan hipertrikosis namun keadaan ini reversibel. Efek samping serius berupa gangguan pertumbuhan, hipertensi, katarak, glaukoma, gangguan psikologis, osteoporosis, infeksi, dan sindrom Cushing tidak lebih 
meningkat pada kelompok intervensi. ${ }^{9} 10,15$

Toksisitas steroid sering menjadi pertimbangan utama pemakaian dosis steroid dalam jangka waktu yang lama. Hal ini membuat Hiraoka meneliti tentang manfaat obat imunosupresif lain yaitu kombinasi prednison dengan siklosporin A untuk mengurangi kejadian relaps. Walaupun hasil yang lebih baik ditemukan pada kelompok yang mendapat siklosporin A, terapi tersebut tidak berbeda bermakna pada pemantauan tahun kedua. ${ }^{13}$

\section{Kesimpulan}

Pemberian prednison selama 12 minggu sebagai terapi inisial SN terbukti dapat menurunkan kejadian relaps dibandingkan terapi standar delapan minggu, tanpa meningkatkan efek samping yang berarti. Pendapat ini membutuhkan penelitian lebih lanjut pada populasi anak Indonesia dengan jumlah subjek yang lebih besar karena belum dapat dibuktikan kemaknaannya secara statistik bila hendak dijadikan rekomendasi nasional. Alternatif lain berupa kombinasi prednison dengan siklosporin A pada terapi inisial tampak memberikan hasil yang baik tetapi belum banyak penelitian yang dipublikasi untuk mendukung terapi tersebut.

\section{Daftar Pustaka}

1. Bagga A, Mantan M. Nephrotic syndrome in children. Indian J Med Res 2005;122:13-28.

2. Trihono PP, Alatas H, Tambunan T, Pardede SO. Konsensus tata laksana sindrom nefrotik idiopatik pada anak. Unit Kerja Koordinasi Nefrologi Ikatan Dokter Anak Indonesia; 2008.

3. Wirya IGNW. Sindrom nefrotik. Dalam: Alatas H, Tambunan T, Trihono PP, Pardede SO, penyunting. Buku ajar nefrologi anak. Edisi kedua. Jakarta: Balai Penerbit FKUI 2004. h. 381-426.
4. Gipson DS, Massengill SF, Yao L, Nagaraj S, Soyer WE, Mahan JD, dk $k$. Management of childhood onset nephrotic syndrome. Pediatrics 2009;124:747-57.

5. Hoyer PF, Brodehl J. Initial treatment of idiopathic nephrotic syndrome in children: Prednisone versus prednisone plus cyclosporine A: A prospective, randomized trial. J Am Soc Nephrol 2006;17: 1151-7.

6. Noer MS. Predictors of relapse in steroid-sensitive nephrotic syndrome. Southeast East Asian J Trop Med Public Health 2005;36:1313-20.

7. Ruth EM, Kemper MJ, Leumann EP, Laube GF, Neuhaus TJ. Children with steroid-sensitive nephrotic syndrome come of age: long term outcome. J Pediatr 2005; 147:202-7.

8. Oxford Centre of Evidence-based Medicine. Oxford centre for evidence-based medicine levels of evidence (March 2009). Diunduh dari: http://www.cebm.net/index. asox?o=1025. Diakses tanggal 19 Oktober 2009.

9. Hodson EM, Willis NS, Craig JC. Corticosteroid therapy for nephrotic syndrome in children. Cochrane Database Syst Rev 2007, Issue 4.

10. Bagga A, Hari P, Srivastava RN. Prolonged versus standard prednisolone therapy for initial episode of nephrotic syndrome. Pediatr Nephrol 1999;13:824-7.

11. Trihono PP, Marwali EM, Alatas H, Tambunan T, Sudung OP. Pengaruh lama pengobatan awal sindrom nefrotik terhadap terjadinya kekambuhan. Sari Pediatri 2002;4:2-6.

12. Noer MS. Long versus standard initial steroid therapy for children with idiopathic nephrotic syndrome. Folia Medica Indonesiana 2005;41:205-10.

13. Hiraoka M, Tsukahara H, Matsubara K, Tsurusawa M, Takeda N, Haruki S, dkk. A randomized study of two longcourse prednisolone regimens for nephrotic syndrome in children. Am J Kidney Dis 2003;41:1155-62.

14. Constantinescu AR, Shah HB, Foote EF, Weiss LS. Predicting first-year relapses in children with nephrotic syndrome. Pediatrics 2000;105:492-5.

15. Ehrich JHH, Broedhl J. Long versus standard prednisone therapy for initial treatment of idiopathic nephrotic syndrome in children. Eur J Pediatr 1993;152:357-61. 